\title{
Perbandingan Klaim Penyakit Katastropik Peserta Jaminan Kese- hatan Nasional di Provinsi DKI Jakarta dan Nusa Tenggara Timur Tahun 2014
}

\author{
Heniwati ${ }^{1}$ Hasbullah Thabrany ${ }^{2}$ \\ ${ }^{1}$ Lulusan Pascasarjana Fakultas Kesehatan Masyarakat Universitas Indonesia \\ 2 Pusat Kajian Ekonomi dan Kebijakan Kesehatan Fakultas Kesehatan Masyarakat Universitas Indonesia \\ Contact: ukhtiheni@gmail.com \\ Reviewed October 20, 2016, and accepted on November 5, 2016
}

\begin{abstract}
Abstrak
Beberapa penyakit yang pada tingkat rumah tangga tergolong katastropik adalah gagal ginjal, kardiovaskular, kanker, thalassemia dan hemophilia. Penderita penyakit tersebut merupakan kelompok yang paling menikmati Jaminan Kesehatan Nasional (JKN) dan penyakit-penyakit tersebut menyerap klaim besar dalam JKN yang perlu mendapat perhatian serius. Karena sebaran fasilitas kesehatan dan kompetensi tenaga medis yang berbeda serta bayaran CBG yang tidak adil, disinyalir terjadi serapan dana yang tidak seimbang antara propinsi. Penelitian bertujuan untuk menganalisis besaran klaim penyakit tersebut di dua proponsi Jakarta dengan pendapatan per kapita tinggi dan NTT dengan pendapatan per kapita rendah. Penelitian ini menggunakan data klaim di BPJS Kesehatan tahun 2014 yang berjumlah 309.301 klaim di kedua propinsi tersebut untuk mengekplorasi sejauh mana perbedaan klaim klaim. Hasil analisis menunjukkan ada perbedaan bermakna rata-rata klaim klaim per CBG, per perawatan, per hari rawat. Faktor terbesar perbedaan tersebut adalah besaran CBG yang tidak memberi insentif pemerataan dokter spesialis ke RS kelas B, C, dan D di daerah dengan pendapatan per kapita rendah. Penelitian ini tidak membuktikan bahwa dana dari provinsi NTT terserap di provinsi DKI.
\end{abstract}

Kata kunci: Penyakit katastropik, klaim klaim JKN, Tarif CBG, Disparitas Rumah Sakit.

\begin{abstract}
Several diseases that at the household level become catastrophic are end stage renal diseases, cardiovascular, cancer, thalasemia, and haemphilia. Patients of those diseases are benefitted the most of the National Health Insruacen (JKN) and those diseases absorbed high claim costs of the JKN. Special attentions are needed to manage those diseases. Disparity of health care facilities, specialists, and differentials of Casemix Base Group (CBG) payment are susptected to be important contributing factors that create absosrbtion of JKN fund across provinces. This study use 2014 claim data of BPJS Kesehatan in Jakarta and East Nusa Tengga (NTT) provinces to explore the size of differences. The total number of claims analyzed was 309,301 claims. The results show statistically difference of claim payment per case, per admission, and per hospital day. The differences are atributable mostly by differentials of CBG prices that are not providing incentives for specialists to be deployed in smaller hospitals of class B, C, and D in low income provinces..This study does not prove transfer of JKN fund from NTT to Jakarta.
\end{abstract}

Key words: Catastrophic diseases, JKN Claims, CBG Prices, Disparity of hospitals.

\section{Pendahuluan}

Penyakit katastropik adalah penyakit yang karena terapinya memerlukan keahlian khusus, menggunakan alat kesehatan canggih dan atau memerlukan pelayanan kesehatan seumur hidup. Akibatnya, penyakit katastropik menyerap klaim kesehatan yang tinggi. Penyakit katastropik pada tinkat rumah tangga yang teridentifikasi antara lain penyakit gagal ginjal, penyakit jantung (yang memerlukan baik tindakan invasif atau noninvasif), kanker, serta penyakit kelainan darah yaitu thalassemia dan hemophilia (Suciati, 2013). Penyakit katastropik merupakan penyakit kronik dan degeneratif. Disebut kronik karena penyakit tersebut bersifat laten yang memerlukan waktu lama untuk bermanifes, sering tidak disadari, dan memerlukan waktu lama untuk penyembuhan atau memerlukan wak- tu seumur hidup untuk mengendalikannya. Disebut degeneratif karena penyakit tersebut semakin sering terjadi seiring bertambahnya usia. Penyerapan klaim yang besar inilah yang menyebabkan munculnya terminologi penyakit katastropik.

Menurut data Organisasi Kesehatan Sedunia (WHO), penyakit kardiovaskular adalah penyebab utama kematian di seluruh dunia. Pada tahun 2012 diperkirakan 17,5 juta orang meninggal karena penyakit kardiovaskular $(7,4$ juta diantaranya disebabkan penyakit jantung koroner dan 6,7 juta kematian disebabkan oleh stroke). Lebih sepertiga kematian akibat penyakit kardiovaskular terjadi di negara berpendapatan rendah dan menengah. Sementara itu, penyakit kanker juga menjadi tantangan besar kesakitan dan kematian di seluruh dunia, dengan perkiraan 14 
juta kasus baru dan 8,2 juta kematian akibat kanker pada tahun yang sama. Infeksi virus viral menjadi penyebab 20 persen kematian akibat kanker di negara berpendapatan rendah dan menengah (WHO, 2015). Di Indonesia, laporan Riskesdas (2013) menunjukkan bahwa prevalensi penyakit gagal ginjal kronis, kasus stroke, penyakit jantung koroner, serta penyakit kanker meningkat seiring bertambahnya umur dan peningkatan tertinggi terjadi pada kelompok umur $\geq 75$ tahun. Sedangkan berdasarkan jenis kelamin, penderita penyakit kanker, diabetes mellitus, gagal jantung serta penyakit jantung koroner lebih banyak ditemukan pada wanita (Kemenkes, 2014).

Tren perkembangan penyakit tidak menular menyebabkan perubahan beban penyakit di Indonesia. Pada tahun 2011, dari total pembiayaan kesehatan yang dilakukan PT. ASKES, sekitar 25 persen dikeluarkan untuk pengobatan kanker (health.kompas.com, 11 Mei 2011). Data International Health Metric Evaluation (2010) sebagaimana dikutop dalam paparan Menteri Kesehatan pada kongres ke-2 INAHEA menunjukkan beban penyakit tidak menular tahun 1990 sebesar 37 persen, meningkat menjadi 49 persen di tahun 2000, dan menjadi 58 persen di 2010 . Klaim rawat inap ke BPJS Kesehatan Januari - Juni 2014 mencapai 735 ribu kasus dengan menyerap dana JKN Rp 4,2 trilyun. Klaim rawat jalan satu juta pasien menyerap dana sebesar Rp 1 trilyun. Jika dibandingkan dengan total klaim klaim, klaim penyakit katastropik rawat inap menyerap 33,5 persen dan rawat jalan menyerap 30 persen total klaim.

Salah satu tujuan pendanaan publik layanan kesehatan adalah mengurangi beban keuangan rumah tangga pelayanan kesehatan (Gani dkk, 2008). Belanja kesehatan katastropi dapat memicu pemiskinan. Oleh sebab itu sistem pendanaan kesehatan dirancang tidak hanya menjamin pemerataan akses pelayanan kesehatan tetapi juga memberi perlindungan bagi rumah tangga dari pengeluaran katastropi. Pengeluaran terus menerus untuk pengobatan penyakit kronis merupakan masalah besar bagi masyarakat, baik miskin maupun tidak miskin. Dampak ekonomi tidak langsung dari penyakit kronis adalah berkurangnya pendapatan karena produktifitas yang hilang akibat sakit atau kematian, berkurangnya kesempatan menabung, dan hilangnya kesempatan bekerja atau memperoleh pendidikan bagi anggota keluarga (Suciati, 2013). Sampai dengan tahun 2013, pendanaan kesehatan rumah tangga di Indonesia yang bersumber dari OOP masih tinggi yaitu sebesar 67,9 persen untuk klaim rawat jalan dan 53,5 persen untuk klaim rawat inap. Dengan JKN pada tahun 2014 diharapkan porsi pembayaran OOP semakin kecil, sehingga tidak ditemukan lagi pemiskinan rumah tangga akibat beban klaim berobat.

Namun, dengan transfer risiko dan gotong royong (sharing risiko).yang dilakukan melalui JKN masih menimbulkan pertanyaan serapan dana klaim. Apakah JKN hanya berfungsi mencegah pemiskinan di kota besar seperti Jakarta ataukah juga berperan di kota kecil seperti Kupang? Seberapa besar perbedaan bayaran klaim di provinsi DKI Jakarta dan di NTT? Apakah JKN mendorong pemerataan layanan di berbagai provinsi? Ataukah JKN mendorong pemusatan layanan di kota-kota besar yang semakin tidak adil? Untuk menjawab pertanyaan tersebut, penelitian ini dilakukan.

\section{Metode Penelitian}

Penelitian ini merupakan penelitian evaluasi dengan menggunakan data sekunder yaitu data klaim penyakit katastropik di Provinsi DKI Jakarta dan NTT tahun 2014. Yang dimaksud penyakit katastropik dalam penelitian ini adalah empat kelompok penyakit (gagal ginjal, kardio vaskuler, kanker, dan gangguan dara yaitu thalasemia dan hemofilia) yang dapat menimbulkan pemiskinan apabila harus dibayar oleh rumah tangga. Seluruh data klaim keempat kelompok penyakit tersebut disediakan oleh BPJS Kesehatan. Analisis data klaim ini dipilih secara sengaja untuk mengevaluasi perbedaan antara provinsi kaya (DKI Jakarta) dan provinsi tidak kaya (Nusa Tenggara Timur). Data yang dievaluasi adalah data klaim tahun 2014. Populasi penelitian adalah seluruh klaim rawat jalan tingkat lanjut (RJTL) dan rawat inap (RI) yang ditagihkan oleh rumah sakit yang dikontrak BPJS Kesehatan di dua provinsi yaitu DKI Jakarta dan Nusa Tenggara Timur pada tahun 2014. Sampel dalam penelitian adalah seluruh klaim kasus empat kelompok penyakit katastropik.

Unit analisis yang digunakan dalam penelitian ini adalah klaim perorangan kepada BPJS Kesehatan yang berasalah dari RS yang dikontrak BPJS Kesehatan di Provinsi DKI Jakarta dan Nusa Tenggara Timur. Data klaim elektronik mencakup variabel usia, jenis kelamin, jenis kepesertaan, jenis pelayanan yang diterima, lama hari rawat, kelas perawatan, kelas rumah sakit serta klaim klaim yang dibayarkan BPJS. Data yang diterima dari BPJS Kesehatan dibersihkan untuk menjamin validitas data. Analisis dilakukan secara univariat dan bivariat untuk menguji perbedaan besaran klaim klaim.

\section{Hasil Penelitian}

\section{Karakteristik Penderita Penyakit Katastropik}

Seluruh data klaim mencakup 93.941 kasus penyakit katastropik, setengah (51\%) dari penderita merupakan kelompok usia 30-59 tahun yang merupakan kelom- 
pok usia produktif. Proporsi terbesar berikutnya adalah kelompok usia lanjut 60-69 tahun yang merupakan $26,9 \%$ kasus dan kelompok usia $\geq 70$ tahun yang merupakan 16,6\% kasus. Penyakit katastropik juga ditemukan pada kelompok usia penderita yang muda (0-29 tahun) hanya sebesar 5,5\%. Di provinsi DKI Jakarta lebih banyak penderita perempuan (52,4\%) dibandingkan dengan pendeerita laki-laki (47,6\%). Sedangkan di Provinsi NTT distribusinya hampir sama antara perempuan dan laki-laki yaitu 49,9 persen dan 50,1 persen.

Sekitar sepertiga $(33,8 \%)$ penderita penyakit katastropik di kedua propinsi adalah peserta Penerima Bantuan Iuran (PBI). Persentase penderita peserta bukan pekerja sebesar $25 \%$, disusul dengan porsi penderita peserta pekerja bukan penerima upah sebesar $21,8 \%$. Persentase terkecil yaitu penderita yang merupakan pekerja penerima upah (19,5\%). Separuh lebih (62,6\%) klaim tahun 2014 merupakan klaim rawat jalan saja, klaim rawat inap saja sebesar 21,3\% dan klaim rawat jalan dan rawat inap mencapai $16,1 \%$.

Rata-rata lama hari rawat (LOS) adalah 5,82 hari dengan standar deviasi 10,48 hari dengn rentang 1-192 hari. Rata-rata hari rawat di DKI Jakarta lebih tinggi (6 hari; rentang 1-192 hari) dibandingkan LOS di provinsi NTT yang 5 hari dengan rentang 1-151 hari. Sebagian besar $85,4 \%$ dirawat di keals III, disusul di kelas I $(9,1 \%)$ dan di kelas II $(5,5 \%)$. Sebagian besar $(47,3 \%)$ penderita di kedua provinsi dirawat di rumah sakit kelas B.

\section{Klaim Penyakit Katastropik}

Dari 93.941 klaim (0,83\% dari total peserta terdaftar), sebanyak 79.908 berasal dari Provinsi DKI Jakarta dan 14.033 dari Provinsi NTT. Di provinsi DKI Jakarta, angka kejadian gagal ginjal adalah 0,05\% dari seluruh peserta,, angka kejadian kardiovaskular sebesar 0,79\%, kanker 0,15\% dan kasus thalassemia dan hemophilia sebanyak 0,01\%. Di provinsi NTT angka kejadian gagal ginjal sebesar 0,01\%, kardiovaskular 0,35\%, kanker sebanyak 0,06\%, dan tidak dilaporkan kasus thalassemia dan hemophilia. Perbedaan angka kejadian dari klaim yang lebih tinggi di DKI bisa jadi karena faktor jarak dan faktor ketersediaan fasilitas.

Rata-rata klaim klaim penyakit katastropik selama satu tahun untuk setiap penderita di kedua provinsi adalah Rp 8 juta dengan standar deviasi Rp 20 juta. Klaim terkecil adalah untuk pengobatan rawat jalan sebesar Rp 88 ribu dan yang terbesar untuk klaim rawat jalan sekaligus rawat inap yang mencapai Rp 350 juta. Total klaim yang dikeluarkan untuk membiayai pengobatan penyakit katastropik di fasilitas kesehatan tingkat lanjutan dalam setahun di kedua provinsi sebesar Rp 786 milyar. Jika dirinci menurut jenis pelayanan, maka rata-rata klaim yang dihabiskan peserta yang melakukan rawat jalan dan rawat inap adalah dua kali besaran rata-rata klaim rawat inap dan 28 kali rata-rata klaim rawat jalan.

Akumulasi rata-rata klaim rawat jalan di Provinsi DKI Jakarta dalam satu tahun per penderita adalah sebesar Rp 1,5 juta dengan variasi Rp 6 juta. Akumulasi klaim rawat jalan satu tahun per penderita terkecil adalah $\mathrm{Rp}$ 88 ribu dan terbesar Rp 113 juta. Untuk rawat inap rata-rata klaim setahun untuk satu orang penderita Rp adalah 16 juta dengan variasi Rp 21 juta. Akumulasi klaim terkecil untuk satu tahun pelayanan rawat inap adalah $\mathrm{Rp}$ 1,3 juta dan terbesar Rp 328 juta. Untuk penderita yang menggunakan rawat jalan sekaligus rawat inap, akumulasi rata-rata klaim selama satu tahun untuk satu orang penderita adalah Rp 31 juta dengan variasi klaim Rp 35 juta. Akumulasi klaim terkecil per penderita adalah Rp 1,9 juta dan terbesar adalah Rp 343 juta.

Di Provinsi Nusa Tenggara Timur rata-rata akumulasi klaim rawat jalan penyakit katastropik dalam satu tahun per penderita adalah sebesar Rp 381 ribu dengan variasi sebesar Rp 550 ribu. Akumulasi klaim terkecil dalam satu tahun untuk pelayanan rawat jalan per penderita adalah Rp 140 ribu dan klaim tertinggi sebesar Rp 17 juta. Un-

Tabel 1. Distribusi Klaim Penyakit Katastropik menurut Jenis Pelayanan di Provinsi DKI Jakarta dan Nusa Tenggara Timur (NTT)

\begin{tabular}{ccccc}
\hline & Rawat Jalan & Rawat Inap & Rawat Jalan \& Rawat Inap & N \\
\hline $\mathrm{n}$ & 58.775 & 20.047 & 15.119 & 93.941 \\
\hline Rata-rata & 1.369 .349 & 13.365 .261 & 28.993 .266 & 8.375 .109 \\
\hline Median & 378.878 & 7.377 .786 & 15.033 .579 & 1.065 .314 \\
\hline St. Deviasi & 6.084 .476 & 19.278 .380 & 34.869 .375 & 20.064 .507 \\
\hline Min & 88.905 & 1.300 .500 & 1.545 .562 & 88.905 \\
\hline Maks & 113.796 .018 & 328.868 .989 & 343.107 .505 & 343.107 .505 \\
\hline Total & $\mathbf{8 0 . 4 8 3 . 5 3 2 . 2 1 7}$ & $\mathbf{2 6 7 . 9 3 3 . 3 9 2 . 7 0 8}$ & $\mathbf{4 3 8 . 3 4 9 . 1 9 7 . 7 4 0}$ & $\mathbf{7 8 6 . 7 6 6 . 1 2 2 . 6 6 5}$ \\
\hline
\end{tabular}


Tabel 2. Rata-Rata Biaya Klaim Penyakit Katastropik per Pasien di Provinsi DKI Jakarta dan di NTT Tahun 2014 menurut Diagnosa Penyakit

\begin{tabular}{|c|c|c|c|}
\hline Kelompok Penyakit & DKI Jakarta & NTT & Total \\
\hline \multicolumn{4}{|l|}{ Gagal Ginjal } \\
\hline $\mathrm{n}$ & 3.894 & 367 & 4.261 \\
\hline Rata-rata & 17.801 .368 & 3.735 .150 & 16.589 .845 \\
\hline St. Deviasi & 25.407 .190 & 3.423 .971 & 24.627 .176 \\
\hline Minimum & 145.200 & 150.400 & 145.200 \\
\hline Maksimum & 151.211 .586 & 29.002 .900 & 151.211 .586 \\
\hline \multicolumn{4}{|l|}{ Kardiovaskular } \\
\hline $\mathrm{n}$ & 63.444 & 11.577 & 75.021 \\
\hline Rata-rata & 7.645 .276 & 4.026 .484 & 7.086 .836 \\
\hline St. Deviasi & 20.667 .226 & 9.237 .532 & 19.393 .185 \\
\hline Minimum & 131.403 & 142.200 & 131.403 \\
\hline Maksimum & 343.107 .505 & 206.234 .137 & 343.107 .505 \\
\hline \multicolumn{4}{|l|}{ Kanker } \\
\hline $\mathrm{n}$ & 11.695 & 2.059 & 13.754 \\
\hline Rata-rata & 11.766 .300 & 6.197 .051 & 10.932 .572 \\
\hline St. Deviasi & 19.469 .071 & 8.746 .403 & 18.376 .417 \\
\hline Minimum & 88.905 & 154.800 & 88.905 \\
\hline Maksimum & 254.863 .334 & 87.898 .588 & 254.863 .334 \\
\hline \multicolumn{4}{|l|}{ Thalasemia\&Hemophilia } \\
\hline $\mathrm{n}$ & 875 & 30 & 905 \\
\hline Rata-rata & 38.742 .987 & 4.951 .312 & 37.622 .821 \\
\hline St. Deviasi & 34.928 .513 & 4.351 .658 & 34.882 .083 \\
\hline Minimum & 155.371 & 142.200 & 155.372 \\
\hline Maksimum & 328.868 .989 & 206.234 .137 & 328.868 .989 \\
\hline
\end{tabular}

tuk pelayanan rawat inap, akumulasi klaim dalam setahun per penderita adalah Rp 6,3 juta dengan variasi klaim sebesar Rp 6,1 juta. Akumulasi klaim terkecil satu tahun untuk rawat inap adalah $\mathrm{Rp} 1,3$ juta dan klaim terbesar mencapai Rp 169 juta. Untuk peserta yang menggunakan layanan rawat jalan sekaligus rawat inap, akumulasi klaim rata-rata satu tahun adalah $\mathrm{Rp} 12$ juta per penderita dengan variasi klaim sebesar Rp 19 juta. Klaim terkecil Rp 1,5 juta dan klaim terbesar adalah Rp 206 juta.

Di Provinsi DKI Jakarta, rata-rata klaim penyakit katastropik per pasien dalam setahun yang tertinggi adalah untuk penanganan kasus thalassemia dan hemophilia yaitu sekitar Rp 38 juta, kemudian kasus gagal ginjal, kanker dan terakhir kardiovaskular masing-masing $\mathrm{Rp}$ 17 juta, Rp 11 juta dan Rp 7 juta. Sedangkan di Provinsi NTT, rata-rata klaim per pasien paling tinggi adalah untuk penyakit kanker yaitu Rp 6 juta, thalassemia dan hemophilia Rp 4,9 juta, kardiovaskular Rp 4 juta dan terakhir gagal ginjal Rp 3,7 juta. Bila dibandingkan di kedua provinsi, maka rata-rata klaim per pasien untuk kasus gagal ginjal, kardiovaskular dan kanker di Provinsi DKI Jakarta lebih tinggi dua sampai tiga kali rata-rata klaim per pasien di Provinsi NTT. Sedangkan untuk kasus penyakit thalassemia dan hemophilia rata-rata klaim per pasien di Provinsi DKI Jakarta adalah 9,5 kali lebih tinggi bila dibandingkan dengan rata-rata klaim per pasien di Provinsi NTT.

Perbedaan Rata-Rata Klaim Penyakit Katastropik Peserta JKN di Provinsi DKI Jakarta dan NTT Tahun 2014 pada setiap penambahan hari rawat

Tabel 3. Klaim Penyakit Katastropik pada Peserta JKN Provinsi DKI Jakarta dan NTT Tahun 2014 menurut Length of Stay

\begin{tabular}{lllll}
\hline Variabel & $\mathbf{r}$ & R2 & Persamaan Garis & p value \\
\hline LOS & 0,568 & 0,323 & $\begin{array}{l}\text { Klaim Penyakit } \\
\text { Katastropik=13,690+0,100*LOS }\end{array}$ & 0,0005 \\
\hline
\end{tabular}

Hubungan lama hari rawat (LOS) dengan klaim penyakit katastropik menunjukkan hubungan yang kuat ( $\mathrm{r}=$ 0,568) dan positif artinya semakin lama LOS, semakin besar klaim penyakit katastropik. Nilai koefisien dengan koefisien determinasi 0,323 artinya lama hari rawat menerangkan 32,3 persen variasi klaim penyakit katastropik. Hasil uji korelasi pearson's maupun regresi linier sederhana tersebut bermakna dengan $p=0,0005$. Dari persamaan garis yang di dapat, dapat diperkirakan persen penambah- 
Tabel 4. Klaim Penyakit Katastropik pada Peserta JKN Provinsi DKI Jakarta dan NTT Tahun 2014 menurut Kelas Perawatan

\begin{tabular}{|c|c|c|c|c|c|}
\hline Kelas $P$ & & DKI Jakarta & NTT & Total & $p$-value \\
\hline \multirow[t]{5}{*}{ Kelas III } & $\mathrm{n}$ & 69.403 & 10.800 & 80.203 & \multirow{15}{*}{0,0005} \\
\hline & Mean & 7.034 .557 & 2.990 .225 & 6.489 .954 & \\
\hline & St. Deviasi & 18.833 .509 & 7.875 .581 & 17.809 .955 & \\
\hline & Minimum & 88.905 & 142.200 & 88.905 & \\
\hline & Maksimum & 343.107 .505 & 206.234 .137 & 343.107 .505 & \\
\hline \multirow[t]{5}{*}{ Kelas II } & $\mathrm{n}$ & 4.094 & 1.050 & 5.144 & \\
\hline & Mean & 16.790 .159 & 7.354 .930 & 14.864 .228 & \\
\hline & St. Deviasi & 23.172 .384 & 8.555 .494 & 21.371 .196 & \\
\hline & Minimum & 165.351 & 1.617 .100 & 165.351 & \\
\hline & Maksimum & 291.506 .645 & 171.857 .620 & 291.506 .645 & \\
\hline \multirow[t]{5}{*}{ Kelas I } & $\mathrm{n}$ & 6.411 & 2.183 & 8.594 & \\
\hline & Mean & 26.347 .553 & 9.563 .246 & 22.084 .097 & \\
\hline & St. Deviasi & 33.355 .217 & 12.168 .556 & 30.346 .614 & \\
\hline & Minimum & 2.081 .100 & 2.155 .500 & 2.081 .100 & \\
\hline & Maksimum & 318.778 .141 & 190.547 .815 & 318.778 .14 & \\
\hline
\end{tabular}

an klaim untuk setiap persen penambahan hari rawat yaitu katastropik di kedua provinsi pada setiap kelas perawatan. setiap penambahan 1 persen lama hari rawat maka klaim Rata-rata klaim setahun penderita yang dirawat di kelas penyakit katastropik akan bertambah 0,1 persen.

III adalah Rp 6 juta, sedangkan untuk kelas II rata-rata

Perbedaan Rata-Rata Klaim Penyakit Katastropik Pe- klaim dua kali lipat lebih tinggi yaitu Rp 14 juta. Untuk serta JKN di Provinsi DKI Jakarta dan NTT Tahun kelas perawatan I rata-rata klaim selama satu tahun ada2014 pada Menurut Kelas Perawatan lah Rp 22 juta. Bila di lihat perbedaan rata-rata klaim Pada Tabel 4 terlihat perbedaan rata-rata klaim penyakit masing-masing provinsi, maka meskipun pada kelas per-

Tabel 5. Klaim Penyakit Katastropik pada Peserta JKN Provinsi DKI Jakarta dan NTT Tahun 2014 menurut Kelas Rumah Sakit

\begin{tabular}{|c|c|c|c|c|c|}
\hline Kelas $\mathbf{R}$ & & DKI Jakarta & NTT & Total & p-value \\
\hline \multirow[t]{5}{*}{ Kelas D } & $\mathrm{n}$ & 2.265 & 3.688 & 5.953 & \multirow{20}{*}{0,0005} \\
\hline & Rata-rata & 8.541 .705 & 4.047 .132 & 5.757 .229 & \\
\hline & St. Deviasi & 17.717 .837 & 5.505 .699 & 11.956 .100 & \\
\hline & Minimum & 132.711 & 153.070 & 132.711 & \\
\hline & Maksimum & 215.529 .114 & 160.189 .863 & 215.529 .114 & \\
\hline \multirow[t]{5}{*}{ Kelas C } & $\mathrm{n}$ & 5.060 & 6.381 & 11.441 & \\
\hline & Rata-rata & 4.985 .595 & 4.006 .868 & 4.439 .728 & \\
\hline & St. Deviasi & 10.794 .742 & 6.060 .613 & 8.500 .075 & \\
\hline & Minimum & 88.905 & 142.200 & 88.905 & \\
\hline & Maksimum & 147.553 .599 & 173.176 .024 & 173.176 .024 & \\
\hline \multirow[t]{5}{*}{ Kelas B } & $\mathrm{n}$ & 40.426 & 3.964 & 44.390 & \\
\hline & Rata-rata & 5.974 .422 & 5.146 .323 & 5.900 .474 & \\
\hline & St. Deviasi & 15.815 .369 & 14.285 .532 & 15.686 .452 & \\
\hline & Minimum & 131.403 & 142.764 & 131.403 & \\
\hline & Maksimum & 306.371 .531 & 206.234 .137 & 306.371 .531 & \\
\hline \multirow[t]{5}{*}{ Kelas A } & $\mathrm{n}$ & 32.157 & - & 32.157 & \\
\hline & Rata-rata & 13.675 .913 & - & 13.675 .913 & \\
\hline & St. Deviasi & 27.220 .086 & - & 27.220 .086 & \\
\hline & Minimum & 141.071 & - & 141.071 & \\
\hline & Maksimum & 343.107 .505 & - & 343.107 .505 & \\
\hline
\end{tabular}


Tabel 6. 10 Diagnosa Penyakit Katastropik Terbanyak di Provinsi DKI Jakarta dan NTT Tahun 2014

\begin{tabular}{|c|c|c|c|c|c|c|}
\hline No & Kode & Diagnosa & Total Klaim & $\begin{array}{l}\text { Frekuensi } \\
(\mathbf{N})\end{array}$ & $\begin{array}{l}\text { Persentase } \\
(\%)\end{array}$ & $\begin{array}{l}\text { Klaim Maksimum } \\
\text { (Rp) }\end{array}$ \\
\hline \multicolumn{7}{|c|}{309.301} \\
\hline 1 & $\mathrm{I} 10$ & Essential (Primary) Hypertension & & 48.216 & 15,59 & 133.071.100 \\
\hline 2 & N180 & End Stage Renal Disease & & 44.029 & 14,24 & 120.451 .860 \\
\hline 3 & N189 & Chronic Renal Failure, unspecified & & 43.349 & 14,02 & 250.000 .000 \\
\hline 4 & $\mathrm{I} 500$ & Congestive Heart Failure & & 30.083 & 9,73 & 169.058 .988 \\
\hline 5 & $\mathrm{I} 251$ & Atherosclerotic Heart Disease & & 24.473 & 7,91 & 190.453 .000 \\
\hline 6 & I119 & $\begin{array}{l}\text { Hypertensive Heart Disease without } \\
\text { (congestive) Heart Failure }\end{array}$ & & 22.817 & 7,38 & 133.835 .401 \\
\hline 7 & $\mathrm{I} 110$ & $\begin{array}{l}\text { Hypertensive Heart Disease with (con- } \\
\text { gestive) Heart Failure }\end{array}$ & & 16.011 & 5,18 & 126.387 .248 \\
\hline 8 & $\mathrm{C} 509$ & Malignant Neoplasm, Breast, unspecified & & 6.660 & 2,15 & 140.430 .276 \\
\hline 9 & I209 & Angina Pectoris, unspecified & & 6.028 & 1,95 & 152.642 .223 \\
\hline 10 & $\mathrm{I} 250$ & $\begin{array}{l}\text { Atherosclerotic Cardiovascular Disease, } \\
\text { so described }\end{array}$ & & 5.172 & 1,67 & 127.854 .766 \\
\hline
\end{tabular}

awatan yang sama, rata-rata klaim di Provinsi DKI Jakarta dua kali lebih tinggi dibandingkan di Provinsi NTT bahkan untuk kelas perawatan satu rata-rata klaim mencapai hampir tiga kali lebih tinggi ( $\mathrm{p}=0,0005)$.

Perbedaan Rata-Rata Klaim Penyakit Katastropik Peserta JKN di Provinsi DKI Jakarta dan NTT Tahun 2014 pada setiap Kelas Rumah Sakit

Berdasarkan tabel 5 rata-rata klaim penyakit katastropik selama satu tahun menurut kelas perawatan tertinggi adalah klaim perawatan di rumah sakit Kelas A yaitu Rp 13 juta. Untuk klaim perawatan di rumah sakit Kelas B dan D rata-rata biayanya hampir sama yaitu Rp 5 juta sedangkan untuk rumah sakit Kelas C klaim perawatannya paling rendah yaitu $\mathrm{Rp}$ 4,4 juta. Rata-rata klaim penderita penyakit katastropik di rumah sakit Kelas B dan C sama baik di rumah sakit di Provinsi DKI Jakarta maupun NTT. Tetapi untuk rumah sakit Kelas D rata-rata klaim di Provinsi DKI Jakarta dua kali lebih tinggi bila dibandingkan dengan klaim di rumah sakit Kelas yang sama di Provinsi NTT ( $\mathrm{p}=0,0005)$.

\section{Sepuluh Diagnosa Penyakit Katastropik Terbanyak}

Dari 309.301 total klaim penyakit katasropik di tahun 2014 didapatkan sepuluh diagnosa penyakit terbanyak di dua provinsi. Penyakit katastropik terbanyak adalah essential (primary) hypertension yaitu 48.216 peserta $(15,59 \%)$ dengan nilai klaim maksimum untuk satu orang penderita sebesar Rp133 juta. Selain itu, dari total 10 penyakit terbanyak, tujuh diantaranya merupakan kelompok penyakit kardiovaskular dengan nilai klaim maksimum mencapai Rp190 juta, dua kasus penyakit gagal ginjal dengan nilai klaim maksimum Rp250 juta dan kasus kanker payudara dengan nilai klaim maksimum Rp140 juta.

\section{Pembahasan}

Analisis klaim JKN di kedua provinsi lokasi penelitian menunjukkan konsistensi tingginya kejadian penyakit kardiovaskular dengan rata-rata klaim per pasien sebesar Rp 7 juta. Namun rata-rata klaim termahal adalah untuk penanganan kasus thalassemia dan hemophilia yaitu Rp 38 juta per pasien. Rata-rata klaim tertinggi adalah untuk penderita yang mengalami rawat jalan dan rawat inap yaitu sebesar Rp 28 juta. Besaran rata-rata klaim tersebut, jelas membuktikan bahwa kasus-kasus yang dianalisis adalah kasus katastrofik yang hampir semua rumah tangga tidak akan mampu membayar sendiri. Bahkan, jika dibandingkan dengan gaji pokok pegawai negeri yang berpangkat IVE dengan masa kerja maksimal, sekitar Rp 6 juta per bulan, maka besaran biaya berobat tersebut jauh diatas gaji pegawai. Disinilah, JKN membuktikan bahwa gotong royong, menanggung biaya berobat peserta yang menderita musibah sakit telah berfungsi. Disinilah peserta harus memahami bahwa dengan menjadi peserta JKN, mereka akan tertolong dan sekaligus akan menolong peserta lain.

Perbedaan rata-rata klaim penyakit katastropik untuk seluruh jenis pelayanan dalam satu tahun di provinsi DKI Jakarta besarnya dua kali lebih tinggi bila dibandingkan dengan rata-rata klaim di provinsi NTT. Bila melihat rata-rata klaim per pasien di masing-masing provinsi, maka untuk tiap jenis penyakit, rata-rata klaim di provinsi DKI Jakarta dua sampai tiga kali lebih tinggi untuk kasus kanker, kardiovaskular dan gagal ginjal, sedangkan untuk kasus thalassemia dan hemophilia nilainya 9 kali lebih tinggi. Perbedaan tersebut, bukan karena mekanisme pasar akan tetapi karena Permenkes No. 59 Tahun 2014 secara sengaja menimbulkan perbedaan tersebut. Tarif 
INA-CBG yang dibedakan secara regional memang diperlukan untuk mengoreksi indeks kemahalan. Akan tetapi, perbedaan yang terlalu besar antara kelas rumah sakit menimbulkan disparitas klaim yang lebih besar lagi.

Tarif CBG yang berbeda jauh menurut kelas rumah sakit dan kelas perawatan menambah seriusnya disparitas antar provinsi kaya dan provinsi miskin. Jumlah RS kelas A dan Kelas B yang diberikan tarif CBG jauh lebih besar, lebih banyak di Jakarta dibandingkan dengan di NTT. Penelitian ini memperkuat penelitian penyakit katastropik peserta Jamkesmas di 10 rumah sakit milik Kementerian Kesehatan oleh Budiarto, dkk (2012). Perbedaan tarif menurut kelas RS mendorong berbagai daerah menaikan kelas RS, bukan karena terpenuhinya kelengkapan dan kompetensi, tetapi lebih didorong untuk mendapatkan insentif bayaran CBG. Kebijakan diskriminatif tersebut tidak mendorong pemerataan dokter spesialis dan fasilitasnya karena insentif yang diberikan justeru kepada RS kelas A dan B yang umumnya berada di kota besar. Sesungguhnya, rancangan awal pembayaran CBG dalam JKN adalah untuk mendorong redistribusi tenaga spesialis dan RS swasta ke daerah. Namun, Permenkes tersebut, termasuk Permenkes penggantinya, tidak memberi insentif redistribusi fasilitas kesehatan dan tenaga kesehatan ke daerah. Inilah tantangan perbaikan JKN ke depan. Jumlah peserta PBI yang tinggi di provinsi NTT juga berkontribusi perbedaan tarif yang tinggi karena untuk peserta PBI dirawat di kelas III, yang tarif CBGnya terendah.

Beberapa RS milik Kemenkes dikategorikan sebagai RS Khusus yang tarif CBGnya jauh lebih besar di rumah sakit kelas A apalagi dibanding RS kelas C dan D yang lebih banyak berada di daerah. Argumen perbedaan kualitas di RS kelas A dan khusus harus dibuktikan dengan penelitian keluaran (outcome) kasus-kasus yang sama. Apakah benar, untuk kasus dengan kode CBG dan tingkat keseriusan (severity) yang sama menghasilkan keluargan yang berbeda besar diantara RS kelas khusus, kelas A, kelas B dan kelas C/D? Jika memang kualitasnya berbeda jauh, maka wajarlah perbedaan tarif CBG tersebut. Hanya saja, asumsi perbedaan kualitas tersebut diragukan banyak pihak.

Selama tahun 2014 fakta kegotong-royongan dalam membantu penduduk yang terkena musibah penyakit katastropik pada tingkat rumah tangga telah dibuktikan. Sebanyak 0,83 persen peserta di dua provinsi menghabiskan dana sebesar 2,62 persen dari total klaim pengobatan di FKTL untuk semua jenis penyakit di 34 provinsi. Inilah esensi asuransi sosial dimana penduduk yang berisiko tinggi dan mengalami musibah sakit yang pengobatannya membutuhkan biaya besar dibantu oleh penduduk yang sehat dan berisiko rendah. Tanpa asuransi sosial, mereka tidak akan terbantu. Di sisi lain, dengan bantuan dari peserta yang sehat dan memiliki pendapatan lebih tinggi, fasilitas kesehatan dapat memberikan layanan sesuai kebutuhan medis tanpa harus mencari sumbangan sebagaimana terjadi di masa lalu. Artinya, beban subsidi silang yang dulu dilakukan oleh RS kini telah diambil alih oleh BPJS Kesehatan. Subsidi silang terjadi antar wilayah yang memungkinkan terwujudnya gotong royong nasiona. Namun demikian, kendali biaya pada sisi demand menjadi keprihatin baru. Jika peserta tidak mengubah prilaku hidup sehatnya, maka biaya klaim yang harus ditanggung bersama akan semakin besar.

Hasil analisis data menunjukkan bahwa kelompok usia 30-59 tahun merupakan kelompok usia terbesar (51,0\%) penderita penyakit katastropik di kedua provinsi. Mereka adalah kelompok usia produktif. Itulah sebabnya WHO mengingatkan bahwa penyakit kronis perlu dikendalikan karena potensi dampak negatif pada rumah tangga dan pada perekonomian suatu negara. Penyakit krnis dan katastropik menurunkan pendapatan keluarga dan produk domestik bruto (PDB) suatu negara/wilayah.

Temuan penelitian ini memberikan peringatan akan risiko penyakit kronis yang katastropik di masa depan karena prilaku penduduk yang berisiko meningkatkan penyakit katastropik tersebut. Kelebihan berat badan serta obesitas pada anak semakin tinggi prevalensinya. Diperkirakan 22 juta anak-anak usia dibawah 5 tahun mengalami kelebihan berat badan. Menurut laporan Riskesdas 2007 prevalensi berat badan lebih mencapai 19,1\% yang terdiri dari berat badan lebih $8,8 \%$ dan obesitas 10,3\%. Laporan Riskesdas (2013) menghasilan perilaku konsumsi berisiko pada penduduk umur $\geq 10$ tahun dengn konsumsi makanan dan minuman manis menapai 53,1\% dan konsumsi makanan berlemak mencapai 40,7\%. Obesitas pada anak memperbesar peluang kematian dini dan disabilitas pada usia dewasa. Studi terkini menunjukkan bahwa kondisi dalam kandungan serta kondisi awal seorang anak sangat menentukan kesehatannya di usia dewasa. Seorang anak tidak dapat memilih di lingkungan seperti apa dia akan lahir dan dibesarkan, termasuk memilih untuk terbebas dari paparan asap rokok. Laporan Survei Demografi dan Kesehatan Indonesia (SDKI) tahun 2012 menunjukkan hampir 70\% pria dewasa di Indonesia adalah perokok aktif. Laporan Riskesdas (2013) menunjukkan proporsi terbanyak perokok aktif setiap hari terjadi pada umur 30-34 tahun. Proporsi perokok setiap hari lebih tinggi pada kelompok berpenghasilan rendah. Proporsi prokok tertinggi pada tahun 2013 adalah di Nusa Tenggara Timur $(55,6 \%)$. 
Pendidikan tentang menjaga kesehatan sejak dini, melalui makanan sehat dan bergizi seimbang, membangun perilaku hidup sehat seperti istirahat yang cukup dan olah raga yang teratur, menghindari kebiasaan buruk merokok dan minum minuman beralkohol penting untuk mengendalikan penyakit katastropik dalam JKN. Dalam jangka panjang investasi pencegahan risiko penyakit kronis di usia dini dapat mengurangi pandemi penyakit kronis yang mahal (katastropik).

Kelompok terbesar penderita penyakit katastropik di kedua provinsi adalah kelompok Penerima Bantuan Iuran (PBI) yaitu 33,8 persen, sejalan dengan porsi peserta JKN yang juga didominasi PBI. Hal itu menunjukkan bahwa penduduk miskin dan kurang mampu telah memiliki akses yang lebih baik ke pelayanan penyakit-penyakit kronis, yang mungkin sebelumnya telah menjadi beban ekonomi bagi keluarga..Disisi lain, perilaku merokok juga lebih tinggi pada kelompok penghasilan rendah. Hubungan antara tingginya perokok dan biaya klaim akan meningkatkan kesadaran semua pihak untuk peningkatan upaya promotif-preventif.

Selain jumlah penderita peserta PBI merupakan porsi terbesar, jumlah penderita peserta Bukan Pekerja dan Pekerja Bukan Penerima Upah merupakan porsi kedua dan ketiga terbesar di kedua provinsi (25,0\% dan 21,8\%). Kesadaran masyarakat untuk secara mandiri mendaftarkan diri pada program JKN merupakan peningkatan kesadaran. Namun, di sisi lain tingginya porsi PBPU yang menderita penyakit kronis akan meningkatkan beban klaim. Masalah timbul apabila peserta kelompok ini hanya aktif membayar iuran ketika sakit dan setelah sembuh mereka berhenti membayar iuran. Oleh sebab itu, perlu senantiasa dilakukan upaya-upaya terobosan untuk dapat mempermudah para peserta membayar iuran disamping pemberlakuan denda sebagai pengenaan sanksi keterlambatan membayar iur bulanan.

Temuan penting lainnya adalah persentase pemanfaatan pelayanan kesehatan oleh PPU dan PBPU lebih tinggi di Provinsi NTT dibandingkan di Provinsi DKI Jakarta (tabel 6.4). Hal tersebut membantah pendapat bahwa dana JKN terserap hanya di kota-kota besar. Sedangkan persentase pemanfaatan pelayanan kesehatan peserta PBI di NTT lebih rendah dibandingkan dengan di Provinsi DKI Jakarta. Keterbatasan akses, yaitu jarak rumah sakit yang jauh, mungkin menjadi beban biaya cukup memberatkan peserta PBI. Untuk mengatasi hal itu, pemda yang bertanggung jawab dapat memberikan manfaat tambahan (top up) dengan membantu biaya transpor. Kondisi geografis pedesaan yang memaksa penduduknya mempunyai aktifitas fisik seperti berladang dan berjalan membuat kesehatan mereka lebih bagus dan terhindar dari risiko penyakit kronis. Peserta PBI di DKI Jakarta dibiayai dana APBD sejak tahun 2012 dan pembagian kartu kepesertaan dipastikan sampai ke tangan mereka sehingga akses ke rumah sakit pun menjadi lebih tinggi. Di lain pihak, peserta PBI di NTT bertempat tinggal jauh dan akses sulit memungkinkan kartu peserta JKN belum seluruhnya terdistribusi. Mereka tidak dapat memanfaatkan pelayanan kesehatan di rumah sakit yang berdampak pada rendahnya pemanfaatan pelayanan kesehatan oleh peserta PBI di NTT. Paparan BPJS Kesehatan menunjukkan bahwa sampai akhir tahun 2015, belum seluruh kartu peserta PBI terdistribusi.

Jika dilihat dari kelas perawatan, $85 \%$ pasien menerima perawatan kelas III, 5,5\% di kelas II, dan 9,1 persen di kelas I. Persentase penderita penyakit katastropik di NTT yang dirawat di kelas I lebih besar dibandingkan dengan persentase kelas I di DKI Jakarta (Tabel 6.7). Hal tersebut tidak lantas menggambarkan tingkat kemakmuran di NTT lebih tinggi dibandingkan dengan di DKI Jakarta, namun sangat mungkin standar kelas rawat I di NTT tidak sebanding dengan standar kelas I di Provinsi DKI Jakarta.Rata-rata klaim rawat kelas I di DKI Jakarta hampir tiga kali lebih tinggi dibandingkan dengan rata-rata klaim kelas I di NTT (tabel 6.15). Dengan perbedaan standar kelas, maka perbedaan besaran klaim mungkin dapat diterima. Hanya saja, penelitian ini tidak bertujuan menilai kesetaraan kualitas layanan antara DKI dan NTT. Penelitian lebih lanjut untuk meningkatkan keadilan (fairness) bayaran ke RS akan mampu menjawab disparitas biaya klaim tersebut.

Sampai dengan 31 Desember 2014, jumlah kepesertaan jaminan kesehatan nasional mencapai 81 persen di DKI Jakarta dan 64 persen di NTT. Dari total peserta, sebanyak satu persen peserta di DKI Jakarta dan 0,42 persen peserta di NTT memanfaatkan pelayanan kesehatan untuk pengobatan penyakit katastropik dengan total klaim pengobatan Rp786 milyar.

\section{Kesimpulan dan Saran \\ Kesimpulan}

Berdasarkan hasil penelitian dapat dirumuskan beberapa simpulan terdapat perbedaan bermakna rata-rata klaim penyakit katastropik diantara tiga kelas perawatan karena perbedaan tarif CBG yang ditetapkan Kemenkes. Selain itu, terdapat perbedaan bermakna rata-rata klaim penyakit katastropik menurut empat Kelas rumah sakit yang juga disebabkan oleh penetapan tarif CBG yang berbeda. Porsi terbesar kejadian penyakit katastropik adalah pada kelompok usia 30-59 tahun, berjenis kelamin laki-laki, 
peserta PBI, dan perawatan di kelas III. Telah terbukti terjadi kegotong royongan dalam total klaim penyakit katastropik untuk 0,83 persen peserta mengambil 2,3 persen dari total klaim di 34 provinsi.

\section{Saran}

Dalam rangka menjamin kendali mutu dan biaya, Kementerian Kesehatan bersama dengan pemda harus memastikan pemerataan ketersediaan fasilitas kesehatan penanganan kasus penyakit katastropik. Disarankan agar Kemenkes melakukan evaluasi penetapan besaran tarif INA-CBG yang lebih berkeadilan antara kelas perawatan dan kelas RS. Pemda seharusnya bisa membantu peningkatan akses bagi penduduk yang tinggal jauh dari fasilitas kesehatan dengan membantu uang transpor bagi pasien dan keluarga yang menunggu. Penelitian lanjutan untuk memperbaiki akses dan kualitas layanan perlu dilakukan secara nasional untuk menghasilkan standar biaya dan standar mutu yang sama untuk seluruh peserta JKN di seluruh Indonesia

\section{Daftar Pustaka}

Abolhallaje, M dkk. 2013. Determinants of Catastrophic Health Expenditure in Iran. Iranian J Public Health.

Apps.who.int/classifications/icd10 di akses bulan Juli 2015

Budiarto, Wasis dan Mugeni Sugiharto. 2012. Klaim Klaim INA CBG's dan Klaim Riil Penyakit Katastropik Rawat Inap Peserta Jamkesmas di Rumah Sakit (Studi di 10 Rumah Sakit Milik Kementerian Kesehatan Januari-Maret 2012). Buletin Penelitian Sistem Kesehatan:Jakarta

Departemen Kesehatan RI. 2007. Modul Pelatihan Dasardasar Teknis Kendali Klaim Dan Kendali Mutu dalam Jaminan Kesehatan. Pusat Pembiayaan dan Jaminan Kesehatan. Depkes RI

Erika, C. Ziller, Andrew, F. Coburn, Stephaniel, Loux, Cahterine Hoffman and Timothy, D. McBride (2001). Health Insurance Access in Rural America.

Feldstein, PJ, (1993). Health Care Economics, $4^{\text {th }}$ Edition. Gani, Ascobat dkk. 2009. Good Practice of Local Health Financing Schemes in Indonesia: Its Contribution Toward Universal Coverage of Health Insurance. Kemitraan Australia Indonesia.

Gani, Ascobat dkk. 2008. Report on Assessment of Health Financing System in Selected Districs and Municipalities. Kemitraan Australia Indonesia.

Hastono, Sutanto Priyo dan Luknis Sabri. 2010. Statistik Kesehatan. Jakarta: PT. Rajagrafindo Persada.

Hastono S.P. (2011), Analisis Data Kesehatan. Depok: Fakultas Kesehatan Masyarakat, Universitas Indonesia. Hajizadeh, M dan Hong Son Nghiem. 2011. Out-of pocket
Expenses for Hospital Care in Iran: Who is at risk of incurring catastrophic payments?. International J Health Care Finance Economi.

Hemophilia.or.id. Di akses Desember 2015

Hughes, Kenneth. 1993. The Epidemiology of Cardiovascular Disease in the Ethnic Groups of Singapore. Japan: SEAMIC.

KBBI. Diagnosa Medis (www.kkbi.web.id diakses tanggal 7 April 2015).

Kementerian Kesehatan RI. 2014. Laporan Riset Kesehatan Dasar 2013. Jakarta.

Kementerian Kesehatan RI. Buku Pegangan Sosialisasi Jaminan Kesehatan Nasional (JKN) dalam Sistem Jaminan Sosial Nasional (SJSN).

Kementerian Kesehatan RI, Profil Kesehatan Indonesia 2013. Kementerian Kesehatan RI, Profil Kesehatan Indonesia 2014. Li, Xiaohong dkk. 2013. Household Catastrophic Medical Expenses in Eastern China: determinants and policy implications. BMC Health Service Research.

Li, Ye dkk. 2014. Catastrophic Health Expenditure and Rural Household Impoverishment in China: what role does the new cooperative health insurance sceme play?. Plos One.

Li, Ye dkk. 2012. Factors Affecting Catastrophic Health Expenditure and Impoverishment from Medical Expenses in China: policy implications of Universal Health Insurance. Bulletin of World Health Organization.

Limwattananon, Supon dkk. 2007. Catastrophic and Poverty Impacts of Health Payments: results from National Household Surveys in Thailand. Bulletin of WHO.

Mills, Ana dan Lucy Gibson. 1990. Ekonomi Kesehatan untuk Negara-Negara Sedang Berkembang. Jakarta: PT. Dian Rakyat.

Moghadam, M Nekoei dkk. 2012. Iranian Household Financial Protection Against Catastrophic Health Care Expenditure. Iranian J. Public Health.

Nasar, I Made, dkk. 2010. Buku Ajar Patologi II (Khusus) Edisi ke-1. Jakarta: Sagung Seto

Notoatmodjo S. 2010. Metodologi Penelitian Kesehatan Jakarta: Rineka Cipta.

Peraturan Presiden Nomor 72 Tahun 2012 tentang Sistem Kesehatan Nasional

Peraturan Presiden Nomor 12 Tahun 2013 tentang Jaminan Kesehatan

Peran Pembiayaan Kesehatan Dalam Membangun Kualitas Hidup Manusia Di Indonesia. 2015. Bahan Paparan Menteri Kesehatan disampaikan pada Kongres ke-2 INA-HEA di Jakarta

Ranocenter.blogspot.co.id. Antara lama di rawat dan hari perawatan. Di akses pada Desember 2015

Raul Mendoza Sassi. (2000). Factors Associated with Health 
Services Utilization, A Population based Study Assesing the Characteristics of People that Visit Doctors in Southern Brazil.

Rendall R. Bovbjerg, Jack Hadley. (2007). Why Health Insurance Is Important, The Urban Institute.

Rilantono, Lily I. 2013. Penyakit Kardiovaskular (PKV). Jakarta: Badan Penerbit FK UI

Somkotra, Tewarit dan Leizel P. Lagrada. 2009. Which Households Are at Risk of Catastrophic Health Spending: experience in Thailand after Universal Coverage. Proquest.

Suciati, Dwi. 2013. Analisis Hubungan Karakteristik Peserta Administration Service Only PT. Global Asistensi Manajemen Indonesia dengan Angka Kunjungan dan Klaim Pennyakit Katastropik Tahun 2011-2012. Tesis: FKM UI Depok.

Sudewi, Ni Made Ayu Sri Ratna. 2013. Protektabilitas Askes Sosial Terhadap Ekonomi Pegawai Negeri di Jawa Tengah dan D.I. Yogyakarta. Tesis: FKM UI Depok.

Thabrany, Hasbullah. 2014. Jaminan Kesehatan Nasional. Jakarta: PT. RajaGrafindo Persada.
Thalassemia.org. Diakses pada Desember 2015

Trisnantoro, Laksono. 2015. Kebijakan Strategis Untuk Mengurangi Ketidakadilan Dalam Mencapai Universal Health Coverage. Bahan paparan disampaikan pada Kongres ke-2 INA-HEA di Jakarta

Undang-Undang Nomor 36 Tahun 2009 tentang Kesehatan

Undang-Undang Nomor 40 Tahun 2004 tentang Sistem Jaminan Sosial Nasional

Undang-Undang Nomor 24 Tahun 2011 tentang Badan Pengelola Jaminan Sosial

Wibowo, Adik. 2014. Metodologi Penelitian Praktis Bidang Kesehatan. Depok: Rajawali Pers.

World Health Organization. 2015. Global Status Report on NCD. WHO, Geneva, 2015

Yasmuarsih, Asianty. Determinan Klaim Kasus Katastropik Pasien Rawat Inap Penyakit Paru JPK-Gakin, Orang Terlantar, Panti dan SKTM di Dinas Kesehatan Provinsi DKI Jakarta Tahun 2010. Tesis. FKM UI: Depok.

$\mathrm{Xu}, \mathrm{Ke}$ dkk. 2007. Protecting Households from Catastrophic Health Spending. Health Affairs. 